\title{
SACRED LANDSCAPES THROUGH THE LENS OF RELIGIOUS NATIONALISM
}

When one tries to comprehend what goes on with sacred geographies in contemporary Eurasia it can be useful to take into account that many phenomena of religious and/or secular sacredness are perceived by people in terms of so-called religious nationalism. I understand religious nationalism here as a particular approach to understanding social reality, an approach that asserts that the human being normally acquires religious identity along with ethnicity in the course of primary socialisation. In practice, religious nationalism is usually both a political program that promotes the utmost convergence of the ethnic and the confessional, and the logic of a social imagination at the grassroots level that sees in the so-called traditional religions a saving means of defence against the expansion of the global information society. This process is perceived as the main threat to the very idea of existence of ethnic nations with their particular cultures, languages, and ways of life.

An important aspect of this fight for maintenance of ethnic nations is the striving for religious ethnicisation of the national geographical landscape. Thus, in Georgia Orthodox churches are erected in the Muslim Adjara region, located next to Turkey to show Turks and local Muslims that it is Georgian land (Serrano 2010). In Russia, the construction of churches of typical OldRussian architecture is intended to make some landscapes look more 'Russian' if their visualised Russian identity is not strong enough. Cases for this kind of development are the Karelian Isthmus, which was a part of Finland before Second World War, and Kaliningrad region (former East Prussia). Another example of a similar activity of Russian Orthodox Church activists and their supporters among secular elites is the building of the churches and chapels in territories that were developed and populated during the Soviet period (for example, Murmansk region) and correspondently have no easily recognisable places of religious worship. Not having them, those landscapes do not look Russian enough. Therefore, religious colonisation takes place in territories that were already colonised by reorganising the sacred geography. One more way to claim symbolically a certain ethnic nation's territorial rights for a sacral location is to re-identify its 'ethnicity' through its religious or confessional identity. Thus, in the capital of Georgia, Tbilisi, one can see how some Armenian churches are presented by local authorities as formerly Georgian. They do this to conceal the Armenian past of central districts of the capital city of the Georgian nation state. We can see the same idea beyond these activities - an ethnic group/nation, which traces its traditional ethnic religion's sacred objects to a certain territory gains primary rights to the whole territory. Among these objects one can list not only churches and, say, mosques but archaeological sites, monuments to historical events and heroes, cemeteries and modest rural sacred places.

This on-going competition for the sacred landscape takes most dramatic forms whenever in a society there is more than one conception of what the real and primordial religion of a certain ethnic group is. Usually, this happens when two ideas of it conflict with each other. The first idea is that the authentic ethnic religion is an ethnicised version of some world religion (such as Islam for Chechens or Orthodox Christianity for Georgians). The second one is based on the pre-

\footnotetext{
* The research was supported by Russian Foundation for Basic Research (RFBR) grant 19-59-22006 Marking the Space Religiously: Comparative Research into the Presence of the Russian Orthodox Church in Russia and France.
} 
supposition that every ethnic group had its own primordial native faith, which was destroyed or at least damaged by the invasion of a world religion and therefore has to be reconstructed (these are nativistic versions of the more general idea of ethnic religion, with the latter term assigning each religion the status of an expression of 'natural' ethnic identity). In such cases, one can speak about different versions of religious nationalism and contention between them (on the conflicts between different religious nationalisms in contemporary Armenia, see Antonyan 2011). These discussions can presuppose a public discussion about the religious identity of ethnic ancient sacred places.

I would like to elucidate this process by presenting my field observations of a conflict between two groups of ethnic religion activists (Orthodox believers vs. ethnic nativists), who propose and promote their own versions of origin and correspondently the religious 'identity' of ancient local shrines in the Republic of North Ossetia-Alania (Northern Caucasus, Russia).

In recent years, local advocates of Orthodox Christianity do their best to form and popularise an image of Ossetian people as a collective bearer of the ancient Orthodox culture that they inherited from their glorious ancestors the Alans, an Iranian people of antiquity, well known from the history of the Great Migration. According to this version of the religious history of Ossetians, the Alans accepted Christianity from Byzantium in the 10th century and the Alans' descendants, the Ossetians, could preserve that faith despite all historical collisions. But the problem is the following: did they really preserve it?

The point is that the acceptance of Christianity by the ancestors of today's Ossetians was followed by the 'exodus' of the institutional church from Ossetia after several centuries of its presence. Without its pastors, the flock found itself without spiritual nourishment for several centuries, that is, it was left to its own devices or, rather, to the care of local elite families. This deprived the Ossetians of more than just the 'instructive word', the spiritual control by the institutional Church. In fact, for many years they ceased to be even nominal Christians, in that there was no one to baptise them.
When the Russian empire began its expansion into the Caucasus, the secular and ecclesiastical authorities strove particularly to return Ossetia to the bosom of Orthodoxy, motivated mainly by ideas of a political character.

The active promulgation of Christianity and the stubborn attempts to introduce religious discipline with respect to catechisation and participation in the sacraments did not change the general portrait of the religious life of the mountain Ossetians, however they did not always and in all respects appear as firm and consistent Orthodox Christians. But one could discern some traits of Orthodoxy in their ritual and everyday life. And the worship of the local shrines - dzuartx (sing. dzuar) - can be considered one of those traits.

Ethnographically speaking, dzuartæ can be described as rural sacred places, whose veneration is expressed through pilgrimage, consisting of visiting the shrines during a calendar feast and/or journeys to them in fulfilment of a vow. In both cases, the pilgrimage entails votive offerings and participation in a ritual feast ( $k u v d)$, set up in immediate proximity to the shrine in a special construction (kuvandon).

These practices are very colourful and wellknown in North Ossetia. So, it is hardly surprising that in the social imagination of local people these shrines embody Ossetian piety, which is being inscribed in the local landscape, anchoring the whole ethnic group and its faith in the native land. The ancient $d z u a r t x$, erected on the steep slopes of the gorges, are becoming the symbol of Ossetia and its ancient culture. That is why it is so important to decide what religion the shrines belong to. That religion would have to be considered the true and legitimate Ossetian one.

Therefore, in recent years, representatives of the Orthodox Church did a lot to demonstrate that the dzuartx are Christian sacred places (indeed, some if not many of these are ancient churches and chapels, sometimes very much in ruins) that through different historical circumstances had fallen into disuse but now are being restored by the Orthodox Church. In this context, Orthodox activists present their Church as an institution whose main activity in the republic proceeds towards preservation of the ethnic 
cultural inheritance (linguistic, architectural, literary, folkloristic, and so forth) and supports relevant social programs (Shtyrkov 2015).

The activities of the Church activists resulted in bitter public discussion in North Ossetia. The more consistent critics of the Orthodox version of Ossetian culture and spiritual heritage are the advocates of the establishment (or reestablishment) of the particular ethnic religion of the Ossetians, sometimes known as 'native faith' advocates (nativists). They present the other version of Ossetian religious nationalism. Ideologically, this includes some New Age ideas and conceptions of the European 'New Right'. The nativists direct their criticism at Orthodox activists' attempts to 'get their hands on' Ossetian culture and first of all-dzuartx. The native faith advocates see in Christianity in general, and in Orthodoxy in particular, a globalisation project entailing the eradication of any ethnic particularities. Their project of recreation of the ethnic religion proposes the purification of everything Ossetian from the 'external' veneer of Orthodoxy and the return of Ossetians to their pre-Christian past, to their 'Indo-Aryan' spiritual roots, which had predetermined the greatness of contemporary civilisation in opposition to Near Eastern religious teachings. For nativists it is very important to stress that $d z$ uartæ are shrines of their religion and symbols of their spiritual motherland while the Christians' main shrines are situated in the Holy Land, i.e. not in Ossetia (and even not in Russia).

In practice, this argument about issues of sacred geography often develops into attempts to assert administrative control over certain local rural shrines. In 2013, someone threw the icons out of the dzuar, a chapel in the village of Kharisdzhin, located not far from the Alanian monastery of the Assumption, and smashed a memorial stone with the sign of the cross. The local Orthodox authorities called this incident a 'violation of the boundaries' and an attempt 'at the seizure of one religion's holy site by representatives of another religion'. But it did not help and the shrine fell under the control of nativists who established a local cell of their religion and proclaimed the shrine to be their place of worship.
As we see, Ossetian nativists' endeavours to reform the sacred geography of the region presuppose a direct relationship between their religious practices and objects of the landscape. When engaging in these activities, they try to legitimate their monopoly to represent publicly the real, authentic religion of the Ossetian people. But they go beyond that when they present themselves and all contemporary Ossetians as the only keepers of great Aryan heritage. Thus, their religious project becomes the reconstruction of an ethnic faith and religion which is almost universal, primordial for many peoples of the Indo-European language family and a foundation for all European culture. In this picture, Ossetia is the sacred centre of the whole Indo-European world, the place where the ancestors of the Ossetians saved the ancient wisdom from the spiritual imperialism of Christianity. This knowledge can be vitally important in the contemporary epoch when the world religions lose the monopoly to produce crucial values and senses. This, in turn, can dramatically change the geographical distribution of sacred territories.

Sergei Shtyrkov

(European University St Petersburg; Museum of Anthropology and Ethnography

[Kunstkamera],

Russian Academy of Sciences)

\section{References}

Antonyan, Yulia. 2011. Religiosity and Religious Identity in Armenia: Some Current Models and Developments. - Acta Ethnographica Hungarica 56 (2): 315-332. DOI: https://doi.org/10.1556/ AEthn.56.2011.2.4.

Serrano, Silvia. 2010. De-Secularizing National Space in Georgia. - Identity Studies 2: 37-58.

Shtyrkov, Sergei. 2015. Orthodox Traditionalism in the Republic of North Ossetia-Alania: The Ethnicization of Religion as the "Internal Mission" of the Russian Orthodox Church. - State, Religion and Church 2 (1): 75-105. 